\title{
An Efficient Method for the Extraction of High-Quality Fungal Total RNA to Study the Mycosphaerella fijiensis-Musa spp. Interaction
}

\author{
Aminael Sánchez-Rodríguez • Orelvis Portal · Luis E. Rojas · Bárbara Ocaña • \\ Milady Mendoza - Mayra Acosta · Elio Jiménez - Monica Höfte
}

(C) Humana Press 2008

\begin{abstract}
Efficient RNA isolation is a prerequisite for gene expression studies and it has an increasingly important role in the study of plant-fungal pathogen interactions. However, RNA isolation is difficult in filamentous fungi. These organisms are notorious for their rigid cell walls and the presence of high levels of carbohydrates, excreted from the fungal cells during submerged growth, which interferes with the extraction procedures. Although many commercial kits are already available for RNA isolation, they do not provide, in most cases, enough amount of pure RNA to be used in upstream applications. In the present work, we propose an easy and efficient protocol for isolating total RNA from the filamentous fungus Mycosphaerella fijiensis, the most important foliar pathogen of Musa spp. varieties worldwide. In addition, we applied the proposed protocol to the isolation of total RNA from banana leaves infected with the pathogen. Our methodology was developed based on the SDS method with modifications
\end{abstract}

Aminael Sánchez-Rodríguez and Orelvis Portal contributed equally to the article.

A. Sánchez-Rodríguez · O. Portal · L. E. Rojas · B. Ocaña · M. Mendoza $\cdot$ M. Acosta $\cdot$ E. Jiménez

Instituto de Biotecnología de las Plantas (IBP), Universidad Central "Marta Abreu" de Las Villas, Carretera a Camajuaní km

5.5, 54830 Santa Clara, Cuba

\section{A. Sánchez-Rodríguez}

Centre of Microbial and Plant Genetics, Faculty of

Bioengineering, Catholic University of Leuven, Kasteelpark

Arenberg 20, 3001 Leuven-Heverlee, Belgium

O. Portal · M. Höfte $(\bowtie)$

Laboratory of Phytopathology, Faculty of Bioscience

Engineering, Ghent University, Coupure Links 653,

9000 Ghent, Belgium

e-mail: Monica.Hofte@UGent.be including a carbohydrate precipitation step. The protocol resulted in high-quality total RNA, from fungal mycelium grown in PDB medium and infected banana leaves, suitable for further molecular studies. The proposed methodology is also applicable to the ascomycete fungus Passalora fulva (syn. Cladosporum fulvum).

Keywords cDNA libraries - Cladosporium fulvum . Mycosphaerella fijiensis - RNA isolation . Infected banana leaves

\section{Introduction}

Isolation of large amounts of intact RNA is critical for a number of molecular genetic analyses such as cDNA production and reverse transcriptase driven analysis.

Mycosphaerella fijiensis Morelet (anamorph: Pseudocercospora fijiensis) is the causal agent of the most destructive foliar disease of bananas and plantains worldwide [1], well known as the black leaf streak disease (BLSD) or Black Sigatoka disease. In order to study the interaction among Mycosphaerella fijiensis and different Musa spp. cultivars, we are particularly interested in the construction of cDNA libraries to screen differentially expressed fungal genes. The success of this approach extensively depends on having a good representation of M. fijiensis mRNA molecules from liquid cultures as well as from infected banana leaves. For this purpose, highquality total RNA is needed. However, RNA preparation, particularly in filamentous fungi, often requires laborintensive practices.

Filamentous fungi are notorious for their rigid cell walls. In addition, the presence of high levels of carbohydrates excreted from the fungal cells during submerged growth 
interferes with the extraction procedures [2]. Carbohydrates not only affect the total RNA isolating process coprecipitating with it, but also, and even more dramatically, the recovery of the poly $\mathrm{A}^{+}$mRNA fraction by blocking matrices used during this step. Although many commercial kits for isolating RNA from diverse sources including fungi are already available, the obtained results do not provide, in most cases, enough amount of pure RNA to be used in upstream applications. Furthermore, such systems are not improved for working with carbohydraterich starting material.

Only one protocol for RNA isolation specific for $M$. fijiensis has been reported [3], which does not consider carbohydrate removal a crucial issue. Instead, this protocol focused on obtaining RNA preparations free of melanins, phenolic compounds naturally produced by many fungi. In that research, authors report a hybrid methodology of commercially available methods.

Here, we present a simple protocol for total RNA extraction from $M$. fijiensis mycelium grown in potato dextrose broth (PDB) medium and infected banana leaves. Some progresses in isolating RNA from plant tissues rich in polysaccharide compounds, like fruit flesh preparations [4], were extrapolated to improve carbohydrate removal from fungal samples. Cleaning steps [5], which are usually not employed in commonly reported protocols, were carried out to minimize interferences during further RNA manipulation and for the removal of phenolic compounds such as melanins. The method produces the required amounts of high-quality total RNA to be used in mRNA purification and reverse transcription-polymerase chain reaction (RT-PCR).

\section{Materials and Methods}

\section{Fungal Material}

M. fijiensis strain CCIBP-Pf-83, belonging to the fungal collection of the IBP, was grown in erlenmeyer flasks containing $50 \mathrm{ml}$ of PDB medium (Difco, Germany) incubated on a rotary shaker $(150 \mathrm{rpm})$ for $2-3$ weeks at $28^{\circ} \mathrm{C}$ (Fig. 1a). Part of the cultured mycelium was washed twice with distilled water, collected, and immediately lyophilized. The remaining fresh mycelium was directly used for RNA isolation and inoculum preparation by mixing it for $1 \mathrm{~min}$ in an Ultra Turrax T25 homogenizer (Rose Scientific Ltd., Canada). The concentration of mycelium fragment suspension was determined by observation under optic microscope (Leitz Wetzlar, Germany) in a Bürker hemocytometer (Brand, Wertheim, Germany).

Passalora fulva (syn. Cladosporium fulvum) strain seven isolated from the tomato (Solanum esculentum) HA3105 hybrid was grown in B5 liquid medium on a rotary shaker at $22^{\circ} \mathrm{C}$. After 7 days, the mycelium was harvested and lyophilized.
Fig. 1 Starting material for total RNA extractions (a): Mycosphaerella fijiensis 15day-old liquid culture (b): M. fijiensis infected 'Grande naine' leaf at stage three of disease progression. The square indicates the area (surrounding a lesion) used for total RNA preparation. Ethidium bromidestained agarose $1 \%$ gel electrophoresis (c): total RNA preparations from an infected plant [1] and fungal [2] material. (d): RT-PCR results using the $M$. fijiensis cytochrome $b$ specific primer on total RNA preparations from a non-infected [1] and infected [2] 'Grande naine' leaf and fungal liquid culture [3]. Molecular weight marker: GeneRuler ${ }^{\mathrm{TM}}$ 100 bp plus DNA ladder, (Fermentas Life Sciences, Lithuania) [4]
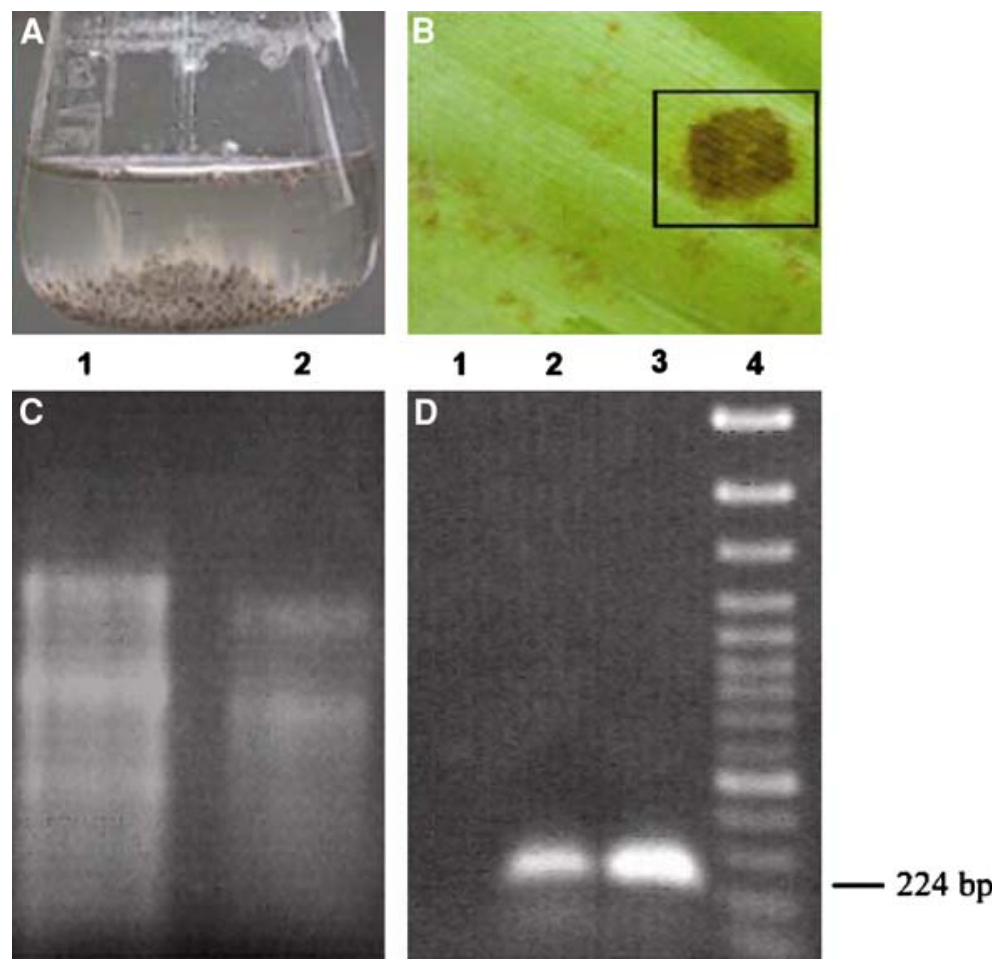


\section{Plant Material}

The susceptible banana cultivar 'Grande naine' (AAA) was propagated in vitro according to the methodology used at INIBAP (International Network for the Improvement of Banana and Plantain) Transit Centre at Katholieke Universiteit Leuven [6]. Rooted plantlets were transferred to greenhouse conditions for 2-3 months on an appropriate substrate (organic matter 20\%, CEC 60 mS/m, pH 5.5-6.5).

Fungal Inoculation Procedure

'Grande naine' banana plants with a height of approximately $20 \mathrm{~cm}$ and four active leaves were infected as described by Alvarado et al. [7]. The first three open leaves were used for the inoculation by brushing the abaxial surface of each leaf with a $1 \times 10^{5} \mathrm{cfu} / \mathrm{ml} M$. fijiensis mycelium suspension. Banana leaves used for total RNA extraction were collected at different stages of the disease progression according to the scale proposed by Alvarado et al. [7] as shown in Fig. 1b. Infected tissues were frozen in liquid nitrogen and maintained at $-80^{\circ} \mathrm{C}$ until used for RNA preparations.

\section{Solutions and Reagents}

The tubes and bottles were treated with $0.1 \%$ diethyl pyrocarbonate (DEPC) solution at $37^{\circ} \mathrm{C}$ overnight, autoclaved twice at $121^{\circ} \mathrm{C}$ for $20 \mathrm{~min}$, and dried at $100^{\circ} \mathrm{C}$ before use.

- Extraction buffer: $0.6 \mathrm{M} \mathrm{NaCl}, 10 \mathrm{mM}$ EDTA, $100 \mathrm{mM}$ Tris-HCl pH 8.0, 4\% SDS (the solution was treated first with $0.1 \%$ DEPC and Tris- $\mathrm{HCl}$ was added after autoclaving was completed). $\beta$-mercaptoethanol was then added to the extraction buffer when used at a final concentration of $2 \%(\mathrm{v} / \mathrm{v})$.

- Clean-up buffer: $100 \mathrm{mM}$ Tris- $\mathrm{HCl} \mathrm{pH} 8.0,0.35 \mathrm{M}$ sorbitol, $10 \%$ (w/v) PEG 6000, $2 \%$ (v/v) $\beta$-mercaptoethanol

- $10 \mathrm{M} \mathrm{LiCl}$ with $0.1 \% \mathrm{DEPC}$

- $5 \mathrm{M} \mathrm{K}$ acetate, $\mathrm{pH} 4.8$

- DEPC-treated water

- Absolute ethanol

- $75 \%(\mathrm{v} / \mathrm{v})$ ethanol

- DEPC water-saturated phenol

- Chloroform

- Chloroform-isoamyl alcohol (24:1, v/v)

- $0.5 \% \operatorname{SDS}(\mathrm{w} / \mathrm{v})$ with $0.1 \%$ DEPC

\section{Total RNA Extraction Protocols}

One gram of either lyophilized mycelium or frozen 'Grande naine' infected tissue (Fig. 1a, b) was placed in a clean cold mortar, and liquid nitrogen was added to keep the material frozen and brittle. The material was then ground to a very fine powder with a pestle and later it was transferred to a $50 \mathrm{ml}$ polypropylene centrifuge tube containing $20 \mathrm{ml}$ of clean-up buffer. The samples were vortexed for $30 \mathrm{~s}$ and centrifuged at $8,000 \mathrm{~g}$ for $10 \mathrm{~min}$ at $4^{\circ} \mathrm{C}$. During the centrifugation step, a volume of extraction buffer (at a ratio of $10 \mathrm{ml}$ per gram of starting material with $2 \%$ of $\beta$-mercaptoethanol) was preheated at $65^{\circ} \mathrm{C}$. The supernatant and the floating cell debris were decanted carefully and the extraction buffer was then added. The pellet was resuspended by vortexing during $30 \mathrm{~s}$ and the tube treated in a water bath at $65^{\circ} \mathrm{C}$ for $10 \mathrm{~min}$ with occasional shaking to mix the content. Afterwards, the tube was cooled to room temperature, and $1 \mathrm{ml}$ of $5 \mathrm{M} \mathrm{K}$ acetate, $3 \mathrm{ml}$ of cold absolute ethanol, $10 \mathrm{ml}$ of phenol, and $2 \mathrm{ml}$ of chloroform were added sequentially and well mixed after each addition. The tube was shaken vigorously to form an emulsion and incubated $30 \mathrm{~min}$ on ice and centrifuged at $12,000 \mathrm{~g}$ for $30 \mathrm{~min}$ at $4^{\circ} \mathrm{C}$. The supernatant was transferred to a new tube, and extracted with chloroform-isoamyl alcohol (24:1, v/v) with gentle shaking for about $10 \mathrm{~min}$ and centrifuged at $12,000 \mathrm{~g}$ for $10 \mathrm{~min}$ at $4{ }^{\circ} \mathrm{C}$. This step was repeated once more, and the supernatant was transferred to another new tube containing 1/4 volume of $10 \mathrm{M} \mathrm{LiCl}$. The content was mixed thoroughly and stored at $4^{\circ} \mathrm{C}$ overnight, and RNA was obtained by centrifugation at $12,000 \mathrm{~g}$ for $30 \mathrm{~min}$ at $4^{\circ} \mathrm{C}$. The RNA pellet was dissolved very gently in $500 \mu \mathrm{l}$ of $0.5 \%$ SDS, extracted with chloroform-isoamyl alcohol $(24: 1, \mathrm{v} / \mathrm{v})$ and then centrifuged at $12,000 \mathrm{~g}$ for $10 \mathrm{~min}$ at $4^{\circ} \mathrm{C}$. The supernatant was again transferred to a $1.5 \mathrm{ml}$ tube, and 2.5 -fold volumes of absolute ethanol was added and mixed thoroughly for precipitating the total RNA for $2 \mathrm{~h}$ at $-20^{\circ} \mathrm{C}$. Subsequently the RNA was pelleted at $12,000 \mathrm{~g}$ for $30 \mathrm{~min}$ at $4{ }^{\circ} \mathrm{C}$, washed in $75 \%$ ethanol twice, dried in a vacuum, re-dissolved in $100 \mu \mathrm{l}$ DEPC-treated water, and stored at $-80^{\circ} \mathrm{C}$ for further use.

We also used the RNA extraction protocol for $M$. fijiensis reported by Islas-Flores et al. [3] starting from $250 \mathrm{mg}$ fresh mycelium. To allow direct comparison with our method, the protocol was also applied on $50 \mathrm{mg}$ lyophilized mycelium (a weight ratio of fresh to dry fungal mycelium of 5 to 1 [8] to was taken into consideration).

In parallel, total RNA preparations were obtained from $100 \mathrm{mg}$ of lyophilized mycelium and frozen 'Grande naine' non-infected tissue, by using the RNeasy ${ }^{\circledR}$ Plant Mini Kit (QIAGEN, Germany) according to the manufacturer's instructions.

The quantity and quality of the isolated total RNA were measured spectrophotometrically (Eppendorf BioPhotometer, Germany) and $5 \mu \mathrm{l}$ run on $1.0 \%$ agarose gel with $1 \times$ TBE (45 mM Tris base, $45 \mathrm{mM}$ boric acid, $1 \mathrm{mM}$ EDTA $\mathrm{pH} 8.0$ ), followed by staining with ethidium bromide. 
Purification of Poly $\mathrm{A}^{+}$RNA from Mycelium-Collected

Total RNA and cDNA First-Strand Synthesis

Isolation of the poly $\mathrm{A}^{+}$RNA fraction was conducted using the Oligotex ${ }^{\circledR}$ mRNA Spin-Column Protocol (QIAGEN, Germany). Only total RNA preparations obtained by the protocol proposed here were loaded in the mRNA isolation columns. Subsequently, $2 \mu \mathrm{g}$ of mRNA was used for the first-strand cDNA synthesis with reagents supplied in the Clontech PCR-Select ${ }^{\mathrm{TM}}$ cDNA Subtraction Kit (BD Biosciences, USA) as appropriate.

\section{M. fijiensis Genomic DNA Extraction}

Genomic DNA from M. fijiensis strain CCIBP-Pf-83 was obtained from $100 \mathrm{mg}$ of lyophilized mycelium using the DNeasy ${ }^{\circledR}$ Plant Mini Kit (QIAGEN, Germany) protocol according to the manufacturer's instructions. The quantity and quality of the DNA were measured spectrophotometrically (Eppendorf BioPhotometer, Germany). To check DNA integrity, $2 \mu \mathrm{l}$ of the DNA preparation was then run on $0.8 \%$ agarose gel with $1 \times \mathrm{TBE}$, followed by staining with ethidium bromide.

\section{RT-PCR and PCR Analysis}

RT-PCR reactions were performed using specific primers to amplify $M$. fijiensis cytochrome $b$ gene (based on AF343069 GenBank accession number), which were designed in a way to know whether the obtained product results from the amplification of genomic or cDNA sequence. Primers used in the reactions were: Mycos fiji cytb forward primer $\left(5^{\prime}\right.$-CCTTATGGTC AAATGTCTTT ATGAGC-3') and Mycos fiji cytb reverse primer $\left(5^{\prime}\right.$ TTACCTGAACCTGCACTATCGTG-3' ${ }^{\prime}$ ).

Access RT-PCR System (Promega, USA) was used according to the manufacturer's protocol starting from $1.5 \mu \mathrm{l}$ of total RNA obtained by our protocol applied to M. fijiensis liquid cultures and infected and non-infected 'Grande naine' banana plants. These primers were also used for PCR amplifications over $20 \mathrm{ng}$ of genomic DNA and $2 \mu \mathrm{l}$ of total RNA preparations as starting template for assessing DNA contamination. The PCR reaction was conducted using $0.5 \mu \mathrm{M}$ of primers, $200 \mu \mathrm{M}$ dNTPs, $1.5 \mathrm{mM} \mathrm{MgCl}_{2}$, and $1 \mathrm{U}$ of Taq DNA polymerase (Fermentas Life Sciences, Lithuania) under the following conditions: Initial denaturation for $2 \mathrm{~min}$ at $94^{\circ} \mathrm{C}, 35$ cycles of $45 \mathrm{~s}$ at $94^{\circ} \mathrm{C}, 45 \mathrm{~s}$ at $55^{\circ} \mathrm{C}$, and $1 \mathrm{~min}$ at $72^{\circ} \mathrm{C}$, with a final extension of $7 \mathrm{~min}$ at $72^{\circ} \mathrm{C}$.

In all cases, before RT-PCR reactions, the RNA was subjected to a rigorous DNAse treatment using the TURBO DNAfree ${ }^{\mathrm{TM}}$ Kit (Ambion, UK) as appropriate.

\section{Results and Discussion}

Total RNA Extraction from Mycosphaerella fijiensis Mycelium

Total RNA was extracted from $M$. fijiensis mycelium using the protocol described in this paper. RNA was also prepared using the RNeasy ${ }^{\circledR}$ Plant Mini Kit (QIAGEN, Germany) since this kit is recommended by the manufacturer for RNA purification from plants and filamentous fungi [8]. We also included the RNA extraction protocol for $M$. fijiensis reported by Islas-Flores et al. [3]. In the first instance, $M$. fijiensis fresh samples were processed as described in the protocol [3]. To allow a direct comparison of the RNA yield obtained, the Islas-Flores et al. [3] protocol was also applied on lyophilized M. fijiensis mycelium. In this case, a weight ratio of fresh to dry fungal mycelium of 1:5 [8] was taken into consideration.

The mean yield of total RNA was $110.6 \mu \mathrm{g} / \mathrm{g}$ of lyophilized mycelium in samples processed by our protocol. When using the Islas-Flores et al. [3] protocol on fresh samples, we obtained an average RNA yield of $40.70 \mathrm{ug} / \mathrm{g}$ mycelium fresh weight, which is in the same range as the values reported [3]. Both isolation methods gave similar yields when applied on lyophilized mycelium. In contrast, a less substantial yield $(25.3 \mu \mathrm{g} / \mathrm{g}$ of lyophilized mycelium) was obtained when the commercial kit was applied (Table 1).

In samples processed with our protocol, the $A_{260} / A_{230}$ ratios were always above 1.9 , while the ratios obtained by the two other protocols were always substantially lower (Table 1). A high $\mathrm{A}_{260} / \mathrm{A}_{230}$ ratio suggests little contamination of polyphenols and polysaccharides [9]. These values show that the present protocol efficiently removes carbohydrates from fungal samples. The presence of sugar residuals in the RNA preparations drastically affects the efficiency of the mRNA isolation procedure. Carbohydrates in the sample may establish hydrophobic interactions with the matrix carrying the oligo dT groups needed for poly $\mathrm{A}^{+}$RNA attachment, which block this process. Initially, we faced these kinds of problems when working with samples with lower $A_{260} / A_{230}$ ratios such as those obtained by the RNeasy ${ }^{\circledR}$ Plant Mini Kit (QIAGEN, Germany) protocol (Table 1).

The $A_{260} / A_{230}$ ratio is also useful as a control for melanin contamination since Dörrie et al. [10] showed that melanin absorbs UV-light over the whole spectrum from 200 to $400 \mathrm{~nm}$. Although the protocol reported by IslasFlores et al. [3] is recommended for the removal of melanins, these authors did not report the corresponding $A_{260} /$ $A_{230}$ ratios. Usually, the presence of melanins in RNA preparations are inferred visually; the clearer the sample the lower the contamination. In our case all the samples 
Table 1 Yield and quality evaluation of RNA obtained from Mycosphaerella fijiensis and Passalora fulva mycelium and M. fijiensis infected banana leaves using different extraction protocols

\begin{tabular}{|c|c|c|c|c|c|}
\hline \multirow[t]{2}{*}{ Fungal species } & \multirow{2}{*}{$\begin{array}{l}\text { RNA isolation protocol } \\
\text { (starting material) }\end{array}$} & \multirow{2}{*}{$\begin{array}{l}\text { Concentration } \\
(\mu \mathrm{g} / \mu \mathrm{l})\end{array}$} & \multicolumn{2}{|c|}{ Absorbance ratios } & \multirow[t]{2}{*}{$\overline{\text { Yield }(\mu \mathrm{g} / \mathrm{g} \mathrm{SM})^{\mathrm{a}}}$} \\
\hline & & & OD $260 / 280$ & OD $260 / 230$ & \\
\hline \multirow[t]{20}{*}{ M. fijiensis } & \multirow{3}{*}{$\begin{array}{l}\text { Own protocol (lyophilized } \\
\text { mycelium from liquid } \\
\text { culture) }\end{array}$} & 0.90 & 1.79 & 1.92 & 90.00 \\
\hline & & 1.50 & 1.99 & 2.35 & 150.00 \\
\hline & & 0.92 & 2.02 & 2.33 & 92.00 \\
\hline & Average & $1.11 \pm 0.30$ & $1.93 \pm 0.12$ & $2.2 \pm 0.24$ & $110.6 \pm 3.40$ \\
\hline & \multirow{3}{*}{$\begin{array}{l}\text { Islas-Flores et al. [3] } \\
\text { (lyophilized mycelium } \\
\text { from liquid culture) }\end{array}$} & 0.15 & 1.84 & 1.67 & 90.00 \\
\hline & & 0.17 & 1.80 & 1.69 & 102.00 \\
\hline & & 0.15 & 1.82 & 1.70 & 90.00 \\
\hline & Average & $0.16 \pm 0.01$ & $1.82 \pm 0.02$ & $1.69 \pm 0.02$ & $94.00 \pm 6.93$ \\
\hline & \multirow{3}{*}{$\begin{array}{l}\text { Islas-Flores et al. [3] (fresh } \\
\text { mycelium from liquid } \\
\text { culture) }\end{array}$} & 0.33 & 1.80 & 1.79 & 40.50 \\
\hline & & 0.35 & 1.79 & 1.77 & 42.00 \\
\hline & & 0.33 & 1.82 & 1.76 & 39.70 \\
\hline & Average & $0.34 \pm 0.01$ & $1.80 \pm 0.02$ & $1.77 \pm 0.02$ & $40.7 \pm 1.20$ \\
\hline & \multirow{3}{*}{$\begin{array}{l}\text { RNeasy }{ }^{\circledR} \text { Plant Mini Kit, } \\
\text { Qiagen (lyophilized } \\
\text { mycelium from liquid } \\
\text { culture) }\end{array}$} & 0.02 & 1.90 & 1.78 & 20.00 \\
\hline & & 0.03 & 1.97 & 2.00 & 30.00 \\
\hline & & 0.02 & 1.89 & 1.72 & 26.00 \\
\hline & Average & $0.03 \pm 0.01$ & $1.92 \pm 0.04$ & $1.83 \pm 0.14$ & $25.3 \pm 5.03$ \\
\hline & \multirow{3}{*}{$\begin{array}{l}\text { Own protocol (fresh } \\
\text { infected banana leaves) }\end{array}$} & 0.46 & 2.00 & 2.10 & 46.00 \\
\hline & & 0.48 & 1.65 & 1.98 & 48.00 \\
\hline & & 0.52 & 1.65 & 1.97 & 52.00 \\
\hline & Average & $0.49 \pm 0.03$ & $1.77 \pm 0.20$ & $2.02 \pm 0.10$ & $48.67 \pm 3.10$ \\
\hline \multirow[t]{4}{*}{ P. fulva } & \multirow{3}{*}{$\begin{array}{l}\text { Own protocol (lyophilized } \\
\text { mycelium from liquid } \\
\text { culture) }\end{array}$} & 6.10 & 1.99 & 2.00 & 610.00 \\
\hline & & 5.87 & 2.01 & 2.01 & 587.00 \\
\hline & & 5.92 & 2.00 & 1.99 & 592.00 \\
\hline & Average & $5.96 \pm 0.12$ & $2.00 \pm 0.01$ & $2.00 \pm 0.01$ & $596.00 \pm 12.00$ \\
\hline
\end{tabular}

a The yield is referred to grams of starting material (SM)

processed by the protocol detailed here appeared transparent after the last step.

In our protocol, the $A_{260} / A_{280}$ ratios ranged from 1.79 to 2.02 indicating that there was little contamination by proteins (Table 1).

Electrophoresis on agarose gel showed distinct and very clear $25 \mathrm{~S}$ and $17 \mathrm{~S}$ bands, which confirm the quality of the total RNA obtained by our protocol (Fig. 1c, line 2). The extracted RNA and mRNA were used for further expression analysis by RT-PCR. According to the experiment setup, a $1.2 \mathrm{~kb}$ fragment indicates the presence of genomic DNA in the total RNA preparation, while a fragment of $224 \mathrm{bp}$, as observed in our assay, indicates no contamination with DNA (Fig. 1d, line 3). To support this result, and to be sure that the absence of a $1.2 \mathrm{~kb}$ product in this reaction was actually due to the absence of genomic DNA more than its presence in low concentrations, total RNA was directly used in excess in a PCR experiment. The reaction yielded no products (data not shown). M. fijiensis genomic DNA was used as a positive control of the PCR reaction giving a sharp product of $1.2 \mathrm{~kb}$ (data not shown).
A key problem in isolating nucleic acids from some fungal materials is that they generate very viscous lysates and large amounts of precipitates in early stages of the isolation procedure. As a result, only low amounts of the clear lysate are recovered. Even after centrifugation, considerable quantities of lysis buffer remain trapped in the interstitial space of the amorphous material formed. To diminish such adverse effects, in all our preparations we settled for $10 \mathrm{ml}$ of extraction buffer per gram of lyophilized material ratio. Previous attempts using a CTAB-based extraction buffer [11] or the one that is reported here, but without the step where the clean-up buffer is added, resulted in the failure of the extraction procedure. Similar results are reported by Islas-Flores et al. [3].

Total RNA Extraction from Infected Banana ('Grande naine') Leaves

Although CTAB-based extraction protocols are not suitable to extract RNA from filamentous fungi, these protocols are 
very efficient when applied to plant material such as banana leaves [5]. Thus, to choose an appropriate protocol to isolate total RNA from $M$. fijiensis infected banana leaves is not trivial, especially since we are particularly interested in the fungal RNA.

In the present work we applied our methodology on infected banana leaves to test whether this protocol could be used to obtain high-quality $M$. fijiensis total RNA from this material, which is the most important feature for the future application of the protocol for molecular studies of plant-pathogen interactions. As a result, we also obtained high-quality total RNA preparations. Electrophoresis on agarose gels analysis showed three distinct bands corresponding to plant $28 \mathrm{~S}, 18 \mathrm{~S}$, and $5.8 \mathrm{~S}$ molecules (Fig. 1c, line 1) when samples from stage three of the disease development were used. No fungal rRNA bands were visible, as we expected and according to the fungal cell concentration in infected leaves.

The mean yield of total RNA was $48.67 \mu \mathrm{g} / \mathrm{g}$ of infected leaves in contrast to $110.6 \mu \mathrm{g} / \mathrm{g}$ obtained from fungal mycelium. $A_{260} / A_{280}$ and $A_{260} / A_{230}$ ratios were similar to those obtained from fungal samples (Table 1).Although the RNA extraction from leaves was evidently less effective in terms of yield, we were more interested in finding whether these total RNA preparations contained enough M. fijiensis RNA suitable for further molecular studies.

To prove that, we performed an RT-PCR reaction following exactly the same experiment setup to the one described above for fungal mycelium. RNA samples from infected leaves corresponding to stages $1-5$ of the disease progression were used. The presence of a DNA fragment of $224 \mathrm{bp}$ (Fig. 1d, line 2) obtained in the samples from stages 3-5 indicated that plant total RNA preparations from infected leaves contained M. fijiensis total RNA as well. However, the amounts of fungal RNA in samples of stages 1 and 2 were not sufficient to get any amplification from them, which is in accordance with the black Sigatoka disease progression in banana leaves. In this reaction, a total RNA preparation from a non-infected 'Grande naine' leaves gave no signal (Fig. 1d, line 1).

\section{Concluding Remarks}

These results confirm the suitability of SDS-based buffers to work with $M$. fijiensis mycelium as well as infected leaves, and the importance of removing the excess of carbohydrates present in fungal cultures in early stages of nucleic acid isolation protocols. The use of the clean-up buffer allows a reduction in the viscosity of the further obtained lysate, not only by removing certain substances in excess, but also by pre-wetting the material. This work confirms that the CTAB method is not suitable to extract RNA from $M$ fijiensis.
These findings could have an important impact in improving the molecular studies intended to study the M. fijiensis-Musa spp. interactions.

Similar results to those described here were also obtained for the fungus Passalora fulva (syn. Cladosporium fulvum), considered a model for functional studies on plant pathogenic Mycosphaerellaceae [12] (Table 1). In this case, an even greater yield of high-quality total RNA was obtained compared to the yield obtained for M. fijiensis, which indicates that this protocol may also be suitable to extract RNA from other fungi. The current protocol is efficient and recommended for isolation of good-quality total RNA from filamentous fungi.

Acknowledgments The authors thank José Gonzalez (Institute of Tropical Crops Research, Santo Domingo, Cuba) for preparation of fungal samples and we are grateful to Frank Maier (Department of Molecular Phytopathology and Genetics, Biocenter Klein Flottbek, Hamburg University, Germany) for providing us with the cytochrome $b$ primers. This research was performed in the frame of the Institutional University Cooperation Programme with Universidad Central Marta Abreü de Las Villas, supported by the Flemish Interuniversity Council (IUC UCLV/VLIR).

\section{References}

1. Pasberg-Gauhl, C., Gauhl, F., \& Jones, D. (2000). Fungal disease of foliage. Sigatoka leaf spots. Black leaf streak. Distribution and economic importance. In D. R. Jones (Ed.), Diseases of banana, abacá and enset (pp. 37-44). Wallingford, Oxford, UK: CABI Publishing.

2. Sokolovsky, V., Kaldenhoff, R., Ricci, M., \& Russo, V. E. A. (1990). Fast and reliable mini-prep RNA extraction from $\mathrm{Neu}$ rospora crassa. Fungal Genetics Newsletter, 37, 15-19.

3. Islas-Flores, I., Peraza-Echevarria, L., Canto-Canche, B., \& Rodriguez-Garcia, C. M. (2006). Extraction of high-quality, melanin-free RNA from Mycosphaerella fijiensis for cDNA preparation. Molecular Biotechnology, 34, 45-50. doi:10.1385/ MB:34:1:45.

4. Hu, C. G., Honda, C., Masayuki, K., Zhang, Z., Tsuda, T., \& Moriguchi, T. (2002). A simple protocol for RNA isolation from fruit trees containing high levels of polysaccharides and polyphenol compounds. Plant Molecular Biology Reporter, 20, 69a69g. doi:10.1007/BF02801935.

5. Liao, Z., Chen, M., Gong, Y., Tang, F., Sun, X., \& Tang, K. (2004). Rapid isolation of high-quality total RNA from taxus and ginkgo. Preparative Biochemistry \& Biotechnology, 34, 209-214. doi:10.1081/PB-200026790.

6. Strosse, H., Van Den Houwe, I., \& Panis, B. (2004). Banana cell and tissue culture-review. In J. S. Mohan \& R. Swennen (Eds.), Banana improvement: Cellular, molecular biology, and induced mutations (pp. 1-12). Inc Enfield (NH), USA: Science Publishers.

7. Alvarado, Y., Leiva, M., Dita, M. A., Acosta, M., Cruz, M., Portal, N., et al. (2003). Early evaluation of black leaf streak resistance by using mycelial suspensions of Mycosphaerella fijiensis. In L. Jacome, P. Lepoivre, D. Marin, R. Ortiz, R. Romero, \& J. V. Escalant (Eds.), Mycosphaerella leaf spot diseases of bananas: present status and outlook. Proceedings of the 2nd international workshop on Mycosphaerella leaf spot diseases held in San José, Costa Rica. The international network for the improvement of banana and plantain (pp. 169-175). Montpellier, France. 
8. Qiagen (2001). RNeasy ${ }^{\circledR}$ Mini handbook, 3rd ed.

9. Warburg, O., \& Christian, W. (1942). Isolation and crystallisation of enolase. Biochemische Zeitschrift, 310, 384-421.

10. Dörrie, J., Wellner, V., Kämpgen, E., Schuler, G., \& Schaft, N. (2006). An improved method for RNA isolation and removal of melanin contamination from melanoma tissue: Implications for tumor antigen detection and amplification. Journal of Immunological Methods, 313, 119-128. doi:10.1016/j.jim.2006.04.003.
11. Sambrook, J., \& David, W. R. (2001). Molecular cloning. A laboratory manual. Cold Spring Harbour, New York: Cold Spring Harbour Laboratory Press.

12. Thomma, B. P. H. J., Van Esse, H. P., Crous, P. W., \& De Wit, J. G. M. (2005). (Cladosporium fulvum (syn. Passalora fulva), a highly specialized plant pathogen as a model for functional studies on plant pathogenic Mycosphaerellaceae. Molecular Plant Pathology, 6, 379-393. doi:10.1111/j.1364-3703.2005.00292.x. 